International Journal of Social Science (IJSS)

Vol.1 Issue.5 February 2022, pp: 693-702

ISSN: 2798-3463 (Printed) | 2798-4079 (Online)

DOI: https://doi.org/10.53625/ijjss.v1i5.1313

\title{
THE HOTEL DEPARTMENT STANDARDIZATION TO IMPROVE STUDENT COMPETENCE IN THE HOUSEKEEPING AND FRONT OFFICE DEPARTMENT THROUGH FIELD INDUSTRIAL PRACTICES IN MATARAM CITY AND WEST LOMBOK
}

\author{
By \\ Firman Koma Febdilan \\ Department of Serving Service Diploma 3 Tourism Polytechnic of Lombok \\ Email: firmankomafebdilans@gmail.com
}

\begin{tabular}{l}
\hline \hline Article Info \\
\hline Article History: \\
Received Nov 10, 2021 \\
Revised Dec 20, 2021 \\
Accepted Jan 23, 2022
\end{tabular}

Keywords:

Competence, Standardization Program for Housekeeping And Front Office

\begin{abstract}
PKL is the term for Field Practice or Professional Placement program. PKL is one systematic implementation within educational programs with mastering skills obtained by undergoing work placement in the working world. The program itself is actually beneficial for students and enterprises. The skills obtained on the campus can be applied in PKL. Hence, it can determine how well students can apply the knowledge and skills derived through the PKL program to become evaluations to develop education quality. The purpose of conducting this research is to determine how the industry's strategy and the steps taken to develop or enhance the skills of the training students in Housekeeping and Front Office, particularly in performing the duties conforming to the predetermined set of the standard by the respective industries. The data collection technique used is observation, interview, literature study, and documentation, which was analyzed using the interactive communication data analysis model by reducing the data, conducting data presentation, and drawing the conclusion. This research results show that the hotelier had applied basic comprehension that the students must know, such as hotel area, hotel property, and the profile of all hotel departments. Additionally, they all implement program standardization after understanding basic product knowledge and dividing work sections in the Housekeeping and Front Office. In Housekeeping, the working standardizations applied are General knowledge of front office, Front Desk Agent, Service center, Bellboy, Guest relation officer. While housekeeping had implemented standardizations such as general training knowledge of housekeeping, room, and laundry.
\end{abstract}

This is an open accessarticleundertheCC BY-SA license.

corresponding author:

Firman Koma Febdilan

Department of Serving Service Diploma 3 Tourism Polytechnic of Lombok

Email: firmankomafebdilans@gmail.com

\section{INTRODUCTION}

The presence of a training workforce is also helpful to assist the existing workforce resources owned by the hotel when the room occupancy rate is very high; additionally, they can also establish a collaboration between college or higher education with the hotel industry to obtain new insight and knowledge. The science obtained by the students as the frontline is undoubtedly beneficial. The knowledge gained at school is a guide and standardization for students to carry out industrial field practices. However, from several occasions when conducting observation and monitoring activities at the Lombok tourism polytechnic college and in the hotel industry, training students got outstanding achievements when practicing in the industry compared to the scores obtained on campus. This increase can be seen from the final outcome of industrial field practices that the industry has provided. The student's Study Report (KHS) score with the same competence obtained is sufficient when viewed backward. So there is a gap between the results of student competency assessments at college and the results of achievements after completing Field Practice; as the example before the Professional Placement, they get a $\mathrm{C}$ mark, but after the program, the 
student gets B grades. In addition, the authors assess the teaching staff whose results are sufficient and not reasonable on the AIS system at Poltekpar Lombok as a reference for the lack of acceptance of competence (knowledge transfer) by students.

Figure 1. Soft File of Study Report for Room Division Study Program Students and PKL certificate
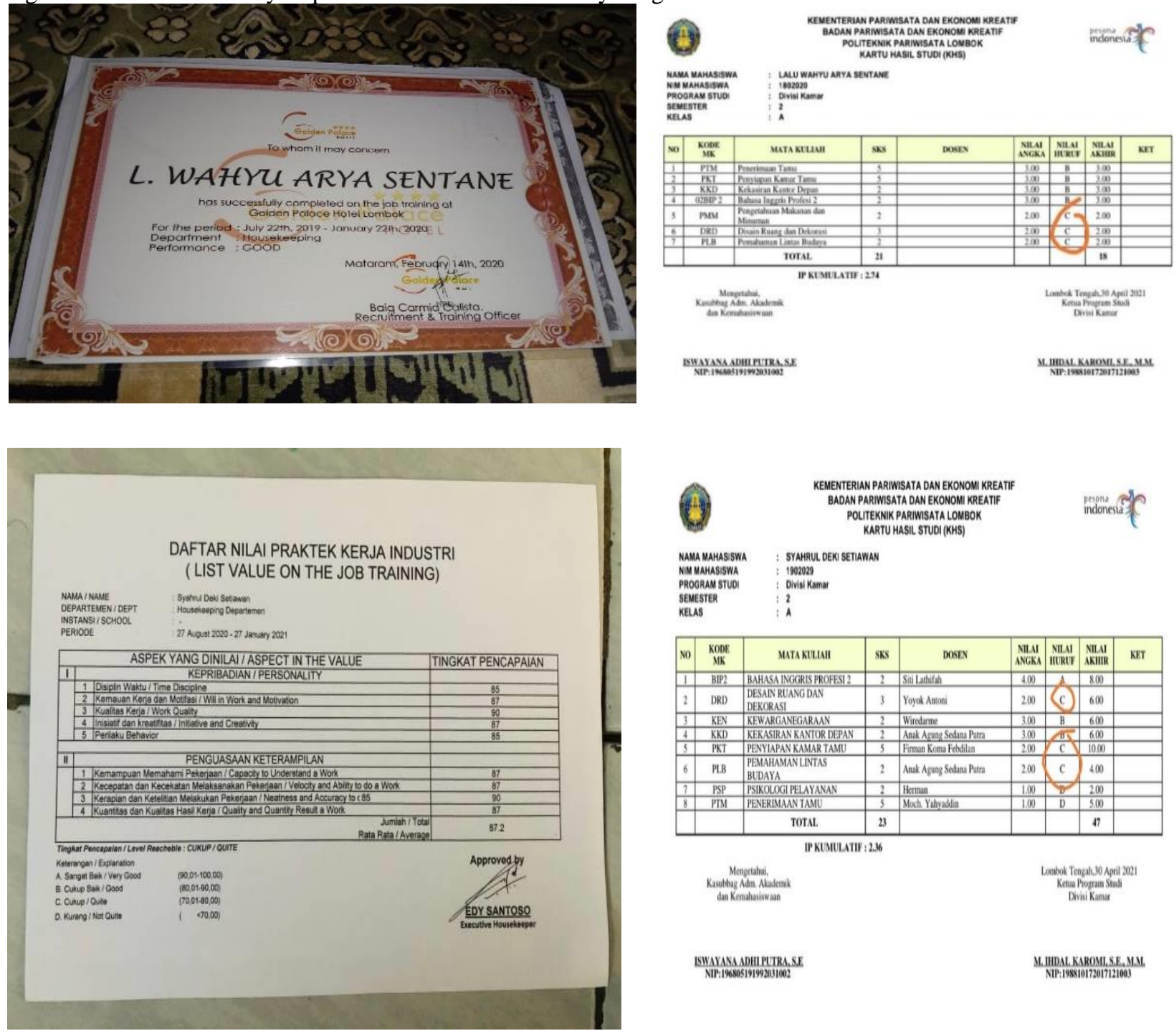

\section{pesona of encosia}

Progenam STUD

KEAS

\begin{tabular}{|c|c|c|c|c|c|c|c|c|}
\hline 0 & KOOE & MАTล КLLAII & sks & DOSEN & $\begin{array}{l}\text { NIIIII } \\
\text { NCKKA }\end{array}$ & 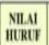 & IIIIII & $\mathrm{KRT}$ \\
\hline 1 & BIP? & BAHASA IVGGES PROFESI? & 2 & Sini Latifift & 400 & & 800 & \\
\hline 2 & DRD & $\begin{array}{l}\text { DEEANRLANG DAN } \\
\text { DEKRORAI }\end{array}$ & 3 & Yoyok Antoni & 200 & (c) & 600 & \\
\hline 4 & $\frac{\mathrm{KEN}}{\mathrm{KED}}$ & 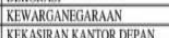 & 2 & Wirderme & 300 & $\mathrm{~B}$ & 600 & \\
\hline$\frac{4}{5}$ & $\frac{\mathrm{PKO}^{\mathrm{PKT}}}{\mathrm{PKT}}$ & 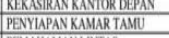 & $\frac{2}{5}$ & 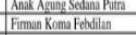 & $\frac{300}{2000}$ & 4 & $\frac{600}{1000}$ & \\
\hline 6 & PIB & PEMAHAMAN LINTAS & 2 & 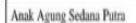 & 200 & $\mathrm{c}$ & 400 & \\
\hline & PSP & PSIKOLOCIPELAYANAN & 2 & & 1.00 & $\nabla$ & 200 & \\
\hline 8 & PTM & PEEERMAANTAMU & 5 & Moch Yitrydin & 1.00 & $D$ & 5000 & \\
\hline & & TOTAL. & w & & & & 47 & \\
\hline & & & & & & & & \\
\hline
\end{tabular}

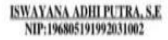

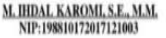

Source: Academic of Diploma III Study Program in Room Division PPL

Figure 2. Soft File of the Evaluation by Teaching Staff of Poltekpar Lombok
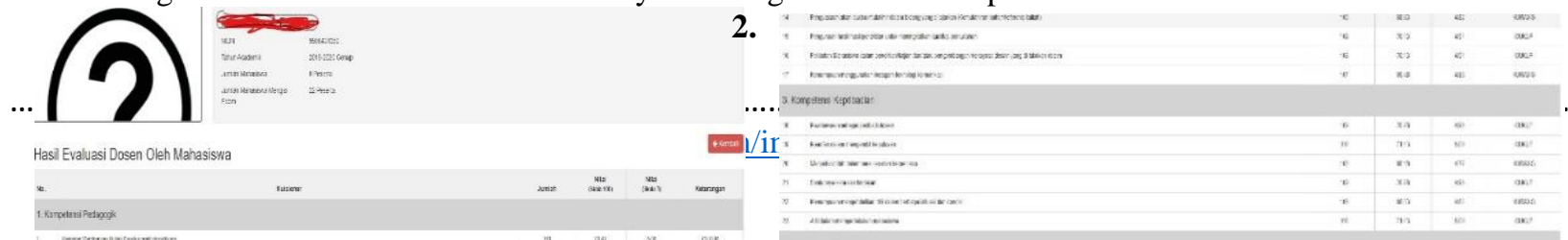


\section{Source: Academic System of AIS Poltekpar Lombok}

Based on the evaluation result and these competencies improvement, the writer also chooses research in West Lombok to add accurate data. The author chooses Lobar because most students assigned to industrial field practice reside in West Lombok. On the one hand, Mataram and West Lombok can also be used as a reference or recommendation for students to field industrial practice because most hotels there are 3, 4, and 5 stars hotels. In addition, the classification of a starred hotel can be used as a reference in terms of services, and the facilities provided have been standardized according to the requirements to become a starred hotel, such as the number of rooms, room types, number of restaurants and human resources that have competency certification. So, if it is associated with student training, it will affect how to provide education or transfer knowledge from the practice module and the practice program. Because the conditions when practicing on campus are different from those of Industrial field practice at hotels, this difference occurs due to inadequate practice support facilities. For example, in practice hotels that are not ready to use, many structures in the hotel building are damaged so that there are still project officers who are active in improving and repairing such conditions within hotel buildings which causes disruption and delays in the learning process.

Therefore, because there are still deficiencies in providing competence to students on campus, it is crucial to know the student's competencies improvement in PKL course in Room Division Study Program in the housekeeping and front office department through field industrial practices at Mataram city and West Lombok.

\section{Formulation of Problems}

1. What is the role of the front office department in hotels in providing standardization of training courses for understanding the work procedures in Mataram city and West Lombok?

2. What is the role of the housekeeping department in hotels in providing standardization of training courses for understanding the work procedures in Mataram city and West Lombok?

\section{Formulation of Problems}

1. To find out the standardization and strategies taken by Hotel industries in providing working system to trainee students/PKL in Front Office and Housekeeping

2. To find out the training procedure in the industry in enhancing the trainee students' competence.

3. To identify the causes of the lack of competence in PKL Students in the Room Division Study Program to undertake their tasks conforming to operational standards during practice on campus.

\section{LITERATURE REVIEW}

\section{Competence in the hospitality sector}

According to (Suwithi \& Boham 2008:499), the definition of competence covers the mastery of three aspects of skills, e.g., knowledge or science, technical skills (skill and technology), and attitude (demeanor). Thus, it can be deduced that competence is the ability to apply and implement knowledge, skill, ability to succeed in performing the task determined by working regulations.

Recently, in various institutions such as hospitality, a competence often becomes standardization of skills which can determine the level of one' knowledge, skill, and ability that is highly needed in the job, and the indicators are as follows:

a. knowledge, science

b. Skill

c. Attitude

\section{Competence Certification}


According to Tourism Act No. 10 of 2009, a tourism competency certification is a shred of evidence for one's competence expertise by providing a certificate to improve the tourism products and services quality and competency management to tourism workers. On the one hand, competence is a skill someone possesses from the world of education and work, both in terms of character and behavior, in developing professional quality work. For obtaining a certificate of recognition of expertise or competence, one must go through the skill-testing stage, either from product knowledge assessment through interviews or from testing of expertise demonstrations through direct practice. A certification agency issues the competency certificate with an official permit or license from the BNSP (National Board for Competency Certification). In the certificate, the skills that have been mastered are written following the Indonesian National Work Competency Standards (SKKNI) in the tourism sector. Every year, a person who has received the certificate will be monitored to maintain quality and competence. This supervision ensures an institution or organization that a person is still competent to produce products or services, plan one's career and assist with the requirements or rules set by the government, support proof of competence between state sectors and contribute to professional development in the labor market.

Field Industrial Practise

Field Industrial practices can provide indirect work experience. The experience gained when undertaking industrial practice can help students learn and understand how the procedures and rules apply to the institution where the student works.

According to Dalyono (2005: 167), the experience can affect individual physiology development, one of the principles for developing a student's readiness (readiness) in preparing to enter the working world. So it can be concluded that experience is very influential on one's level of mastery and understanding in specific fields.

Hamalik (2007:93) describes several benefits of fieldwork practise as follows;

a. Provide opportunities for participants to practice management skills in actual field situations.

b. Provide practical experiences to participants so that the training results are more comprehensive.

c. Participants have the opportunity to solve various management problems in the field by empowering utilizing their respective abilities.

d. Bringing and assisting the participants' preparation to enter their field of work after taking the training program.

From the description above, it can be concluded that industrial field practices provide new knowledge and insights to the individual concerned and can train individuals to be more creative and skilled and help the mindset to be capable and prepared in solving a problem. Industrial field practice also helps bridge individuals' readiness to enter the job market.

\section{Front Office Department}

According to Bagyono (2006) in rosy, Mukti, and Rahayu (2020: page 2) article, says that Front office is a department in the hospitality industry that is located at the front of the hotel, adjacent to the lobby and not far from the guests' sight and easily seen by guests. Hence, the Front office department has several sections in supporting it is operational, among others are:

1. Information is a part or section of mailing administration that constitutes a hotel operational's central part.

2. Reservation is the section assigned to serve the guest booking who will stay in the hotel.

3. The cashier is responsible for handling guests' payments after using their rooms when check-in and checkout in a good, friendly and polite manner according to standard operating procedures to serve the staying guests.

4. The telephone operator is the section in charge and is responsible for handling incoming calls, both from within the hotel and from outside the hotel relating to hotel and place of work information, and serving the necessary needs related to hotel service information.

If one looks at the operational system in the front office department, it is very dense and numerous, so many hotel employees say that the nerve center or the heart of hotel information is in this department. Similar to what Sihite (2000:4) said, the Front Office is a part of management that has the task and responsibility of selling rooms through prior reservations (booking), without reservations (walk-in guests), and then registering. Afterward, they show or let the guests see the rooms that have been booked. So for guests, this department is the nerve center or the main operational activity and plays a crucial role.

\section{Housekeeping Department}

According to Oktazana (2017), she explained that housekeeping has the meaning of house, which means building, home, guesthouse, building, inn, and hotel. At the same time, keeping means keeping, nurturing, and caring. When combined, the two words become housekeeping or in the Indonesian language is 'Tata Graha,' the department in charge of cleaning, maintaining, organizing, and managing facilities, both inside and outside the hotel and informing all damage in it. The maintenance aims to make the environment look attractive, clean, neat or 
International Journal of Social Science (IJSS)

Vol.1 Issue.5 February 2022, pp: 693-702

ISSN: 2798-3463 (Printed) | 2798-4079 (Online)

DOI: https://doi.org/10.53625/ijss.v1i5.1313

organized, pleasant and comfortable for guests who stay. According to Putri (2015), she reveals that there are some supporting sections to assist the operator in Housekeeping Department, they are as follows:

1. The floor section is the housekeeping section responsible for the guest's room maintenance, cleanliness, tidiness, and beauty to give a comfortable impression to guests staying in them. Officers in this section are often referred to as room attendants.

2. Houseman Section/Public Area Section is part of the housekeeping department in charge of cleaning public areas inside and outside the hotel. Officers in this section are often called housemen or public area attendants.

3. Linen/Uniform is the section in charge of handling, supplying, storing, and maintaining linen that has been used by other departments such as banquets, floor sections, food and beverage service, food and beverage products, front office uniforms for all hotel employees. Officers in this section are often referred to as linen and uniform attendants.

4. Laundry is responsible for handling washing and maintenance services such as guest laundry, uniform, and house laundry. Guest laundry is defined as guest clothes, while house laundry is linen used in several hotel departments, and the uniform section has a special duty to wash the clothes of all hotel employee uniforms. Officers who are in this section are often referred to as Laundry attendants.

\section{Standard Operating Procedure}

In its development, the front office and housekeeping are two inseparable departments in its operation. Every job description in each department is made systematically and written. Every job worked on has its predetermined set of rules and stages not to be separated from the existing standard operating procedure. According to Orbani (2017:58), the standard operating procedure is the documented standard procedures and contains a set of business processes of a job that has instruction and the authority for a direction or guide to do the work.

\section{RESEARCH METHOD Type of Research}

This research employs a qualitative descriptive method. The research location is conducted in several hotels in the Mataram area. Time estimation for undertaking this research is started from March until May. The techniques used to collect data are questionnaires, interviews, observation, and direct interaction with the students related to the research focus. Hence, these methods can answer the existing formulation of problems. The Questionnaire and interview will be dedicated to PKL students in Room Division Department

Time and Research Location

This research location is in Lombok, precisely Mataram city, and West Lombok at several 3 to 5 Starred hotels. The writer carries out this research in Mataram city from 16 until 18 April 2021.

\section{Data Source}

Data Source is one way to find the data needed to support the research object. Based on this explanation, the data sources in this study are divided into two, namely primary data and secondary data.

\section{Data Collection Technique}

Data collection techniques in this study are observation, interviews, literature study, and documentation.

\section{Data Analysis Technique}

In this study, the researcher uses qualitative data analysis. In analyzing the data for the research object, the writer uses the Miles and Huberman interactive data analysis model (Miles, Huberman dan Saldana, 2014: 14).

\section{RESULT AND DISCUSSION}

\section{Observation and Interview Result in Mataram City}

In conducting observations and interviews with hotel employees, the researcher also uses an instrument that refers to the practical handout used as teaching material in the room division study program. The author treated some hotels as samples in this research activity, namely the Golden Palace Hotel, Lombok Raya Hotel, Lombok Plaza Hotel, and Lombok Astoria.

In selecting the research sample, there are five sections that the author has compiled into the observation and interview instruments based on the practicum handout used by the lecturers at the Lombok Tourism Polytechnic, among others:

1. Implementation of the basic program for improving industrial training competencies

2. Standard operating procedures for training work at the front office department

3. Standard operating procedures for training workers in the housekeeping department

4. Industry practice assessment criteria 
The explanation of the interviews and observations results that the author has identified at the Mataram city hotel is as follows:

\section{Implementation of the Basic Program for Improving Industrial Training Competence}

There are several department competency development models that the hotel implements on the first day of training including, giving an initial class in the meeting room to introduce staff or employees who work in the department. This is done to instil a sense of brotherhood among the workers and the character of the hospitality hotelier. In addition, students will be introduced and required to know the hotel area, hotel facilities, or hotel property and all departments' profiles at the hotel.

\section{Standard operating procedures for training work at the front office department}

In the beginning, during the interview and observation, the author briefly was explained about the Front office department by FO staff in Mataram city, such as the front office department, which is located in front of and not far from the front door of the hotel lobby to make it easier for guests to come and go from the hotel. In this department, the skills needed are speaking and handling guests manually and with a computerized system. So, many employees and industrial field practice students in Mataram should be advised to take care of their appearance and work procedures. In terms of work appearance or grooming, almost all hospitality industries must maintain their appearance because they include primary products to sell services. The services provided must be well trained and organized. The standard practice program implemented every month is a general introduction to the products sold in the front office department, such as a basic understanding of personal hygiene (Grooming), tools or facilities used by front office staff, and daily activities carried out at the FO counter. Based on operations, the Front office management set training programs including service center/e-commerce, guest service agents, bellboy procedures, and guest relations officers.

\section{Standard operating procedures for training workers in the housekeeping department}

Based on the results of the author's observations and interviews with the housekeeping office department, as well as in the front office, generally, they explained that the Housekeeping office department is a department whose functions and duties are to clean, tidy up and provide comfort for guests staying and doing activities around the hotel environment where they work. Unlike the front office department, this HK department is located behind the hotel or basement. The goal is that everything related to garbage or dirt, cleaning tools, and materials is not visible to the guests' sight while working. This department's fast and precise work system is also highly emphasized because they have to work extra hard. It is highly recommended that employees or employee training have excellent conditions compared to the FO department (front office). Therefore, this department has a standard training program that is applied like a front office department, such as a general introduction to the housekeeping department. At the beginning of an entry in the first month, trainees will be taught about the work organization structure and, most importantly, the grooming SOP and an overview of the department. In the second month, they will be taught about the basic concepts of making beds and how to clean guest rooms. After that, the third stage was given a working understanding of washing guest clothes, linen/cloth, and amenities in guest rooms. Month IV, trainees study the system on order takers because order takers, in this case, play an essential role in communicating all the needs of the housekeeping department to all units. In the last month / fifth month of training, students will be taught the system or procedure for cleaning sections in the public area.

\section{Industry practice assessment criteria}

An assessment of the quality of training work is needed to find out the results of trainee work achievements as evidenced by the assessment sheets provided by the hotel to train students to provide subjective assessments during work. In general, the industry in Mataram provides an understanding or description of work assessment starting at the beginning of work/training. In this case, several things are essential when assessing, such as appearance (grooming) during work, which is needed during work because to sell products, you must have a good appearance when selling everything. In addition, discipline is needed to maintain work professionalism to implement SOPs properly. When the SOP has been carried out properly, it requires an attitude with fellow employees to work well with fellow teams (teamwork) and have reasonable confidence to instil work motivation among fellow employees. From the several sections that have been explained, each main section has a standard rating such as very good, good, sufficient, poor, and not good. This value will provide a self-evaluation or awareness of employees/training during activities.

\section{Description of observations and interviews results in West Lombok}

When conducting observations and interviews with hotel employees, the authors also use the same instrument in these activities as in Mataram city. The authors used several hotels as samples, i.e.,

$\begin{array}{ll}\text { 1. } & \text { Jayakarta Hotel } \\ \text { 2. } & \text { Aruna Hotel } \\ \text { 3. } & \text { Svarga Hotel }\end{array}$


International Journal of Social Science (IJSS)

Vol.1 Issue.5 February 2022, pp: 693-702

ISSN: 2798-3463 (Printed) | 2798-4079 (Online)

DOI: https://doi.org/10.53625/ijss.v1i5.1313

4. Killa Senggigi Beach Lombok

In this case, the data collected from interviews and observations refer to the modules used in Lombok tourism colleges, such as:

1. Implementation of the basic program for improving industrial training competencies

2. Standard operating procedures for training work at the front office department

3. Standard operating procedures for training workers in the housekeeping department

4. Industry practice assessment criteria

Of the four programs provided, the explanation of the interviews and observations results that the author has identified at the West Lombok hotel is as follows.

Implementation of the basic program for improving industrial training competencies

In general, there are several basic programs provided by the hotel in West Lombok to improve a trainee's initial understanding when starting work. In this case, employees will be given special classes to understand the work system and work area at the beginning of work. Each department has its own trainer when working. Unlike the city of Mataram, West Lombok hotels have the same concept as a resort. Consequently, most of the guests who stay are for vacation and sightseeing because the resort hotel is located in several tourist attractions in West Lombok. A trainee who works at this hotel will be provided with a basic explanation on how to serve guests properly. The basic comprehensions provided to an employee on the job training is::

1. The basic concept of service

2. Understand the work section area

3. Hotel properties.

Discussion of Research Results

In discussing this study's results, the author uses the research problem formulation as the basis for answering the results in this sub-chapter.

\section{Standardization of Training Programs in Front Office Departments in Mataram and West Lombok}

Based on the results of interviews that the author has conducted, it is determined that the training program methods that must be known, such as hotel areas, hotel facilities (hotel property), and profiles of all departments in hotels on the industrial side, have several reasons. First, it starts from the hotel area, which one must know so that the training students or new employees know which areas must be passed while working, making it easier to place the work section. The hotel has a division of work paths, and guest access points are divided into two applied terms, such as the front of the house and the back of the house. The front of the house is an area that guests can pass during activities or while staying, such as Lobbies and Reception areas, Restaurants and Bars, Corridors, Lifts, public toilets, Function rooms, Gyms, swimming pools, Car parks. While the back of the house is a path or road access that can only be passed by employees or training workers while working, such as Kitchens, Staff cafeteria, Staff locker rooms, Administration offices, Staff toilets, laundry \& linen rooms, and storerooms

After understanding the work area, trainees are instructed to understand hotel property/facilities such as receptionists, room amenities, swimming pool, restaurant, bar, entertainment, and outbound programs. In this case, all hotel facilities must be known to the location by the trainees because one of the guest needs or guest needs that employees must know. The basic concept of hotel management is asking employees to understand this hotel's facilities because the activities and wishes of guests during their stay must be adequately served. So that when guests will ask about this, all employees can communicate it well and wholeheartedly. After understanding the hotel facilities and how to serve such service, a training employee will be asked to understand the functions of several departments in the hotel in general, such as the front office department, housekeeping department, food and beverage service, and food products.

The training will be specifically asked to focus on each department area of the three services that must be known. At the beginning of the training program, students will be shown several training programs that must be achieved so that before participating in the training program, students read first at home what to do. In this case, the author focuses on the programs scheduled by the hotel based on the research titles, including the Front Office Department Program and the Housekeeping Office Department Program. follows:

In the implementation of such training program, the job division carried out in front office department are as

1. General knowledge of front office

2. Front Desk Agent.

3. Service center.

4. Bellboy

Journal homepage: https://bajangjournal.com/index.php/IJSS 
5. Guest relation officer

The training program description in which the author has identified and discussed is based on the training program at the front office, such as:

\section{General Knowledge Of Front Office}

In implementing reasonable standard operating procedures in several of the hotels' at Mataram city, at the beginning of the first month of training, they will be explained about standard grooming, personal hygiene, front office equipment, and preparation of work in the service of staying guests, including:
a. Hair hygiene
b. Man
c. Women
d. Face, Nose, and teeth
e. Body
f. Hand and Foot
g. Uniform
h. Front Office Equipment.
i. Work preparation
j. Fasilitas dan harga kamar

\section{Front Desk Agent.}

This section is most important when trainee students are in hotels around the city of Mataram. Based on the observations and interviews results, it can be concluded that the student's duties and responsibilities are the same as the employees. The training students have similar duties with the provisions that have been set, of course with supervision and direction from the trainer. In monitoring working time, the trainers will ask the training staff to master the duties and responsibilities of the front desk agent. The explanation of the training program steps in this section is as follows :

1. Filling out timesheets and logbooks at the front office department

2. Ensure that the grooming (appearance) of the training officers is clean, tidy, and does not have bad breath.

3. Always make sure, before guests enter the guest room or check-in, a trainee has marked (blocked) the room according to guest requests such as room type and other requests.

4. Check the number of occupied rooms and prepare a list of guests who will come according to requests from guests.

5. Register guest identities and prepare room keys by ensuring that guest rooms are ready for sale (vacant clean) beforehand. The registration process is a photocopy of identity such as ID card/sim/passport/visa, by always making sure to fill out the guest check-in manual form and most importantly asking for the length of stay at the hotel, giving breakfast coupons, and explaining restaurant opening times and check-out times the guest room.

6. Good mastery and understanding of the payment system when guests check-out using debit, cash, credit cards, bank transfers, bills to companies (guarantee letters), billing bills to travel agents and payments via EDC machines.Menguasai jumlah kamar hotel, harga masing-masing type of room dan room status di system computer, fasilitas kamar dan informasi lainnya yang berkaitan dengan kebutuhan tamu menginap.

7. Mastering how to enter guest data when making guest reservations in the system correctly and adequately.

8. Mastering and understanding the steps for house bank payments by looking at the shift change logbook and cash outflows.

9. Communicate by telephone correctly and adequately according to the SOP by mentioning the name and department in a polite and friendly voice.

10. Consistently maintain and clean the cleanliness of the front desk area by cleaning the available facilities when employees have free time and are about to go home.

\section{Service Center}

In this section, training students will be asked to understand the work procedures of the service center section, understand how to talk to guests, be friendly, polite and the words spoken must be clear and easy to understand. In addition, students will be asked to know how to receive telephone calls from outside the hotel and inside the hotel and connect guest requests to other sections according to the requested needs. In this case, the essential thing that trainees must know is the ring tone characteristics of the incoming telephone because the number of telephone rings from inside the hotel and outside the hotel is different. Their daily duties and responsibilities 
International Journal of Social Science (IJSS)

Vol.1 Issue.5 February 2022, pp: 693-702

ISSN: 2798-3463 (Printed) | 2798-4079 (Online)

DOI: https://doi.org/10.53625/ijss.v1i5.1313

include recording every call, both from outside and inside the hotel, receiving facsimile services and making bills, providing internet wifi services to guests, informing wake-up call services, handling emergency calls, maintaining the privacy of guests staying related to information provided and consistently fast and responsive in handling complaints from guests.

Bellboy

In this case, the author found several programs when students were placed in bellboys, such as carrying out the duties and responsibilities when he had to serve individual guests, groups, and check-out guests. The procedures for handling individual guests who have just arrived at the hotel such as opening the door by saying greeting and mentioning the name of the hotel such as "welcome to the golden palace hotel" or using a foreign language, unloading guest luggage, and placing it in the trolley and asking guests to go to the lobby, escort guests to the room by explaining the facilities and services provided at the hotel, opening the room door and allowing guests to enter, and explaining the facilities available and closing the door slowly. Meanwhile, for group guests, a trainee will be asked to prepare a rooming list from the front desk by preparing a welcome drink, asking the tour lead (guide) about the number of items to be transported to the trolley, and writing the rooms and the guests identity who will be escorted to the room. After guests stay, the next thing is the procedure for handling guests who will check out with a note that there is information on guests who will check-out from the front desk. After that, come to the guest room to provide luggage transportation services by asking guests whether they need a taxi call service or have their driver prepare stand-by in front of the lobby. Next, the bellboy transports the luggage to the trolley to be placed in the lobby neatly and puts it into the guest's vehicle neatly and very carefully. The last thing to do is say goodbye and thank you for coming and staying overnight with guests, and do not forget to take notes to Bell Captain Control Sheet.

Guest Relation Officer

Based on the results of interviews that the author conducted with several GRO staff (Guest Relation Officer) in West Lombok and Mataram, it can be determined that trainee students who are placed to become GRO must be able to become a bridge or intermediary between guests and hotel employees in their operations. Some of the standards that have been set are welcoming group guests warmly, looking at the list of room orders for VIP guests and handling them when they arrive at the hotel, and greeting them with a very warm greeting. The next task is to fill out the GRO checklist, check the date and month of the guest's birth to be given a surprise cake, adjust the data in the VIP schedule with the data in the information rack and room rack, provide and prepare orders for the complimentary VIP, make a daily VIP schedule, view the guest list who come and most importantly always read the logbook to update the existing information.

Standardization of Housekeeping Department Training Programs in West Lombok and Mataram

Referring to the formulation of the problem and interview results, the authors conclude that the standardization of student training programs in the housekeeping department in West Lombok and Mataram is :

1. General Knowledge of Housekeeping

2. Room

3. Laundry

The explanation of the training program that the author has identified and discussed is based on the training program in the Housekeeping department, such as:

1. General Knowledge of Housekeeping.

2. Room

1. Briefing.

2. Preparation

3. Makeup room

\section{CONCLUCION}

Based on the discussion results from the formulation of problems mentioned in the previous chapter, it can be concluded as follows:

1. The standardization of the hotel in providing competency programs to training students in the front office department is perfect and focused based on the SOP that has been implemented. Standardization is to understand work procedures at service centers, guest service agents, bellboy guest relations officers and provide fundamental understanding such as general knowledge before working in several sections in the front office.

2. The standardization of the hotel in providing competency programs to training students in the housekeeping department is appropriate based on the SOP that has been implemented. standardization is to understand work 
procedures in room and laundry and provide fundamental understanding such as general knowledge of housekeeping before going to work in several section areas

\section{SUGGESTION}

Based on the conclusions of the research results above, the authors propose suggestions to the front office and housekeeping department, as follows:

1. Universities need to improve the competence of their students through programs that have been carried out by the hotel for students who will be training. So, when they work, they have the competencies that hoteliers want. In addition, the campus also needs to improve and create special programs for the PKN unit before they go to industrial training.

2. The industry must have a controlling list in implementing the program when students attend training to reduce and minimize errors at work. In addition, it is necessary to role-play a service procedure before dealing with guests from the program so that their mentality and motivation are high.

3. The hotel industry needs to conduct a competency test every month to measure student understanding in work. So, at the end of the program, HRD makes a written test or practical exam and interviews regarding understanding during training at the hotel.

\section{REFERENCES}

[1] Andini, D.M., Rohaeni, N., \& Ningsih, P.M., (2016). Peningkatan Penguasaan Pengetahuan Public Area Melalui Penggunaan Media Proyeksi Padapeserta Didik Di SMK Negeri 15 Bandung. Family Edu.

[2] Bandi. B., Siswandari. S., \& Susilo. A., (2014). Pengembangan Modul Berbasis Pembelajaran Saintifik Untuk Peningkatan Kemampuan Mencipta Siswa Dalam Proses Pembelajaran Akuntansi Siswa Kelas XII SMA n I Slogohimo 2014. Jurnal Pendidikan Ilmu Sosial, Vol 26, No.1, Juni 2016, ISSN: 1412-3835.

[3] Chouhan, S.V., \& Srivastava, S. (2014). Understanding Competencies and Competency Modeling A Literature Survey. IOSR Journal of Business and Management (IOSR-JBM)

[4] e-ISSN: 2278-487X, p-ISSN: 2319-7668. Volume 16, Issue 1. Ver. I (Jan. 2014), PP 14-22.

[5] Dalyono, M., (2005). Psikologi Pendidikan. Jakarta: PT Rineka Cipta.

[6] Didalam Vindy Alvionita, A.H.G. Kusumah dan Sri Marhanah: Persepsi Karyawan Hotel Terhadap Manfaat Sertifikasi Kompetensi Pariwisata Bidang Perhotelan di KotaBandung. https:/lejournal.upi.edu/index.php/Jithor/article/viewFile/13766/8069. (diakses tanggal 26 april 2021).

[7] Devy, A.H., \& Soemanto, B.R., (2017). Pengembangan obyek dan daya tarik wisata alam Sebagai daerah tujuan wisata di kabupaten Karanganyar. Published by Lab Sosio, Sosiologi, FISIP, UNS.

[8] Hamid, H., (2019). Knowledge, Skill, dan Attitude Dalam Dunia Kerja. https://sis.binus.ac.id/2019/03/19/knowledge-skill-dan-attitude-dalam-dunia-kerjal. (diakses tanggal 16 April 2021).

[9] Hamalik, O., (2007). Manjemen Pelatihan Ketenagakerjaan Pendekatan Terpadu. Jakarta: PT Bumi Aksara.

[10] Oktazana, Dian., (2017) Koordinasi Kerja Front Office Department Dengan Housekeeping Department Di Aston Karimun Hotel. JOM FISIP Vol. 4 No. 1 - Februari 2017.

[11] Orbani, Ludfi., (2017) Housekeeping Passport (Manajemen Operasional Housekeeping LANJUT). Yogyakarta: Andi.

[12] Putri H.D.E \& Wicaksono Fajar., (2015) Peranan Housekeeping Dalam Meningkatkan Kenyamanan Tamu Di The Sahid Rich Yogyakarta. Jurnal Khasanah Ilmu-volume 6 No 2-2015-lppm3.bsi.ac.id/jurnal

[13] Rosyid N.A.,Mukti A.N ., dan Rahayu Emik., (2020) Analisis Komunikasi Antara Front Office Dan Housekeeping Di Melva Balemong Hotel \& Resort, Kab. Semarang. Jurnal Hospitaliti dan Pariwisata Edisi 3 Volume 1 (2020).

[14] Sihite, Richard, 2000. Hotel Mangement. Surabaya: Penerbit SIC

[15] Suwithi, W.N., \& Boham, Jr.E.C., (2008). Akomodasi perhotelan. Direktorat Pembinaan Sekolah Menengah Kejuruan. 